\title{
OUTCOME OF ERADICATION OF CHRONIC HEPATITIS C VIRUS INFECTION WITH DIRECT ACTING ANTIVIRAL AGENTS ON BLOOD SUGAR CONTROL AND INSULIN RESISTANCE IN PATIENTS WITH TYPE 2 DIABETES MELLITUS
}

\author{
By
}

\author{
Arafat Kassem *, Mabrouk Mahmoud Aboelenin ** \\ and Mohamed Abdelhamid Khedr ***
}

\author{
Department of Internal Medicine, Faculty of Medicine, Al- Azhar University *, \\ Department of Medical Biochemistry, Faculty of Medicine, Al- Azhar University** and \\ Department of Clinical Pathology, Faculty of Medicine, Al- Azhar University***
}

\begin{abstract}
Background: Hepatitis C virus (HCV) infection is considered to increase the possibility of incidental type 2 diabetes mellitus (Type $2 \mathrm{DM}$ ) in prone subjects, independent to the stage of liver disease. The approaches through which $\mathrm{HCV}$ infection initiates T2DM include direct effects of $\mathrm{HCV}$, insulin resistance, proinflammatory cytokines and other immune-mediated mechanisms.
\end{abstract}

Objectives: Assessing the outcome of direct acting antiviral drugs for therapy of chronic $\mathrm{HCV}$ infection on insulin resistance and blood sugar control in type 2 diabetes mellitus.

Patients and Methods: This study was carried out on 270 type 2 DM patients with genotype 4 chronic HCV. 240 patients were exposed to direct acting antiviral agents (DAAs) in the form of sofosbuvir plus daclatasvir with or without ribavirin for 12 weeks, while the residual 30 patients did not give DAAs and used as a control group. Patients who attained the sustained virologic response (SVR) 12 weeks after DAAs (226 patients, 94.2\%) were categorized into three groups based on the end-point of blood sugar control, i.e. the achieved blood sugar control group with chronic hepatitis (group A) which composed of 83 patients (36.7\%), the achieved blood sugar control group with liver cirrhosis child A (group B) which comprised 76 patients $(33.6 \%$ ), and the non-achieved blood sugar control group with liver cirrhosis child B (group C) which included 67 patients $(29.6 \%)$.

Results: In group A, 30 patients (36.1\%), and group B, 25 patients (32.1\%) required to decrease the dose of antidiabetic therapy. There were no statistically significant variations between our groups as regard to age, sex, and body mass index (BMI). Patients in group C (Liver cirrhosis Child-Pugh classification B with nonachieved blood sugar control) have positive family history of type 2 DM and prolonged duration of DM if compared to group A, and group B.

Conclusion: In type 2 diabetic patients with chronic HCV, the usage of direct acting antiviral agents led to a substantial improvement in blood sugar control and should be closely observed for antidiabetic dosage reduction to halt hypoglycemic events. Eradication of $\mathrm{HCV}$ ameliorates insulin resistance as demonstrated by a reduction of plasma insulin, HbA1c, and HOMA-IR. Achievement of diabetic control in HCV patients treated with direct acting antiviral agents was of great value, especially in patients with mild liver disease (Child-Pugh class A), short duration of diabetes, and negative family history of T2DM, but was not correlated to body mass index, age, and sex.

Key words: Type 2 Diabetes mellitus; Hepatitis C virus; Direct-acting antiviral agents. 


\section{INTRODUCTION}

Chronic hepatitis $\mathrm{C}$ virus (HCV) infects about 170 million subjects over the world and is a principal cause of chronic liver disease, including liver cirrhosis and hepatocellular carcinoma (Bose and Ray, 2014). Egypt account for the most frequent region contracting $\mathrm{HCV}$ infection all over the worldwide (15\%), and genotype $4(90 \%)$ is the most predominant one (Amer et al., 2015). The therapy for hepatitis $\mathrm{C}$ virus (HCV) has prominently modified since the recent evolution of direct-acting antiviral agents (DAAs). DAAs have improved the sustained virologic response (SVR) rate to over $90 \%$ with minimal adverse events and shorter duration of therapy. The short period of treatment enables for an obvious comparability of the biological changes in the body pre and post eradication of $\mathrm{HCV}$ (Bachofner et al., 2017).

$\mathrm{HCV}$ infection is almost associated with metabolic alterations, including insulin resistance, impaired fasting glucose, hepatic steatosis, and lipid metabolic abnormalities (Kaddai and Negro, 2011 and Hashim et al., 2017). It is wide acceptable that $\mathrm{HCV}$ infection is linked to multiple metabolic abnormalities including hypolipidemia, hepatic steatosis and metabolic syndrome (Kawaguchi et al., 2011, Huang et al., 2013 and Chang, 2016). Various studies have also established an increase in the widespread prevalence of blood glucose abnormalities in HCV patients as compared to controls (Dai et al., 2015, and Pandya et al., 2017). So, the virus has been concerned with the development of insulin resistance (IR) by modification of cellular gene expression and impeding insulin signaling pathways.

Patients with chronic HCV infection has a significantly higher prevalence of insulin resistance (IR) and type 2 diabetes mellitus (type $2 \mathrm{DM}$ ), irrespective of the stage of liver disease if compared to controls or infected patients with hepatitis B virus (HBV) (Dawood et al., 2017). $\mathrm{T} 2 \mathrm{DM}$ is one of the most prevalent noncommunicable diseases throughout the world, affecting about one-third of individuals with chronic $\mathrm{HCV}$ infection (Naing et al., 2012, Group IDFDA., 2015, and Cho, 2016). Increasing evidence suggests that $\mathrm{HCV}$ raises the risk of incidental type 2 diabetes mellitus (T2DM) in predisposed subjects (White et al., 2008, Eslam et al., 2011 and Meissner et al., 2015). The mechanism by which $\mathrm{HCV}$ initiates type 2 diabetes mellitus is insulin resistance (Eslam et al., 2011 and Negro, 2014). HCV was demonstrated to impede the hepatocyte insulin signaling pathway by several mechanisms (Kaddai and Negro, 2011), including the induction of tumor necrosis factor- $\alpha$ (TNF- $\alpha$ ) production, upregulation of the serine phosphorylation of the insulin receptor substrates (IRS), the over-expression of the suppressor of cytokines (SOC-3) (Persico et al., 2009) and stimulation of SOC-7 (Pazienza et al., 2010). However, although $\mathrm{HCV}$ affects mainly the liver, the whole body insulin sensitivity is also compromised in chronic HCV patients independent of the metabolic syndrome, as evidenced by the studies of (Vanni et al., 2009) and (Milner et al., 2010). This means that the infected hepatocytes might produce proinflammatory cytokines that induce bioactive endocrine actions at extrahepatic sites, such as the skeletal 
muscle. The virus-mediated metabolic effects, may act on host-related genetic and environmental factors, aggravating insulin resistance and perhaps leading to the occurrence of incidental T2DM (Vanni et al., 2016).

The aim of this study was to assess the outcome of direct acting antiviral drugs for therapy of chronic $\mathrm{HCV}$ infection on insulin resistance and blood sugar control in patients with type 2 diabetes mellitus.

\section{PATIENTS AND METHODS}

This study was carried out on 270 patients with type II diabetes mellitus and had genotype 4 chronic HCV and was collected from the outpatient clinics of the Departments of Internal Medicine and Tropical Medicine of Al-Azhar University Hospitals between July 2016 and June 2017. All patients with chronic HCV genotype 4 infection, for 20 years or more were included in this study. The exclusion criteria included the following conditions: positive HBsAg, human immunodeficiency virus infection, autoimmune hepatitis, hemochromatosis, a1-antitrypsin deficiency, and Wilson's disease. The study protocol was approved by the Ethics Committee of the Al-Azhar University Faculty of Medicine, and the chosen subjects gave their informed consent to be involved in the study.

Two hundred forty patients given the DAAs consisting of sofosbuvir plus daclatasvir with or without ribavirin for three months, while the other 30 patients did not take DAAs and used as a control group. Baseline clinical and demographic data (age, sex, weight, height, body mass index (BMI), ascites, encephalopathy, duration and family history of type $2 \mathrm{DM}$ and anti-diabetic medications) were determined. Laboratory values including liver enzymes, total bilirubin, albumin, prothrombin time, international normalized ratio (INR), Child-Pugh score, alpha-fetoprotein (AFP), creatinine, glycated hemoglobin (HbA1c), Fasting plasma glucose (FPG), insulin, homeostatic model assessment insulin resistance (HOMA-IR), quantitative HCV-RNA by polymerase chain reaction test, total cholesterol, high density lipoprotein cholesterol (HDL-C), and lowdensity lipoprotein cholesterol (LDL-C) were analyzed. Post-treatment demographic (weight, height, and body mass index) and laboratory investigations (fasting plasma glucose, plasma insulin level, HbA1C, and HOMA-IR, alpha fetoprotein, and quantitative HCV-RNA by PCR) were done at the time that sustained virologic response at 12 weeks (SVR12) was achieved. The degree of liver disease was assessed by using the Child-Turcotte-Pugh score (CTP). None of our patients developed ascites or encephalopathy. Only patients with CTP class A and B were included. During the study duration, all patients were encouraged to keep their usual diet regimen and normal physical activity. Diabetes was confirmed by the insulin level, hemoglobin A1c >6.5\%, and fasting plasma glucose $\geq 126 \mathrm{mg} / \mathrm{dL}$ or 2 hour post load glucose $\geq 200 \mathrm{mg} / \mathrm{dl}$. For better evaluation of advancement in blood sugar control, we used a composite endpoint given by a decrease in fasting plasma glucose (FPG) or HbA1c.

As a result to the post-therapy performed SVR after 12 weeks (226 patients, 94.2\%), patients were subcategorized into three groups according to the endpoint of blood sugar 
control, i.e. the achieved blood sugar control group with chronic hepatitis (group A) which composed of 83 patients $(36.7 \%)$, the achieved blood sugar control group with liver cirrhosis child A (group B) which comprised 76 patients $(33.3 \%)$, and the non-achieved blood sugar control group with liver cirrhosis child B (group C) which included 67 patients $(29.4 \%)$.

\section{Statistical Analysis:}

The data were analyzed using the statistical package for the Social Sciences Software (version 25.0; SPSS Inc., Chicago, IL) package. Independent Student's t-test was used to test the differences in the mean values for the continuous variables, Chi-square test was used to test the differences in the proportion of the categorical variables, and analysis of variance (ANOVA) test was used when more than two groups were compared using Tukey test. The Pearson correlation coefficient ( $r$ ) was used to determine the correlation between variables. Multivariate logistic regression was used to adjust the confounding factors. Statistical significance was set at $\mathrm{P}<0.05$.

\section{RESULTS}

Two hundred seventy consecutive adult patients, 158 females $(58.5 \%)$ and 112 males $(41.5 \%)$ with mean age $41.4 \pm$ 12.2 years of them, 240 patients were treated for chronic HCV and were concluded in this study. The mean body mass index was $26.5 \pm 4.6 \mathrm{~kg} / \mathrm{m}^{2}$, with normal BMI in $4(1.7 \%)$ patient, overweight in 168 (70\%), and obese in 68 $(28.3 \%)$ patients. Sustained virologic response (SVR) after 12 weeks of direct acting antiviral agents (DAAs) occurred in 226 patients $(94.2 \%)$. According to the improvement in fasting plasma glucose and/or glycated hemoglobin 3 months after DAA therapy, we classified our patients into three groups: group A which composed of 83 patients with chronic hepatitis $\mathrm{C}$ and improved blood sugar control, group B which comprised 76 cirrhotic Child-Pugh class 'A' patients and improved blood sugar control, group C which included 67 cirrhotic ChildPugh class ' $B$ ' patients with nonimproved blood sugar control. In group A, 30 patients $(36.1 \%)$ needed to decrease the dose of antidiabetic treatment; 5 of 11 patients needed to reduce the insulin dose and 25 of 69 patients needed to reduce the Gliclazide dose, while 5 patients with no medications showed a significant reduction in both FPG and HbA1c. In group B, 25 patients $(32.1 \%)$ needed to decrease the dose of antidiabetic medications; 4 out of 7 patients needed to reduce the insulin dose and 21 of 66 patients needed to reduce the Gliclazide dose. In group C, 11 patients (14.3\%) needed to reduce the dose of antidiabetic medications; 6 out of 52 patients decreased the insulin dose, and 5 out of 25 patients decreased the dose of oral hypoglycemic drugs. None of the achieved blood sugar control patients (group A and B) needed to reduce the dose of metformin or dipeptidyl peptidase-4 (DPP4) inhibitors. There were no statistically significant variations between our groups as regard to age, sex, weight, height and body mass index (BMI). Patients in group $\mathrm{C}$ (Liver cirrhosis Child-Turcotte- Pugh class B with Non-achieved blood sugar control) had positive family history of type $2 \mathrm{DM}$ and prolonged duration of $\mathrm{DM}$ if compared to groups A, and B (Table 1). 
OUTCOME OF ERADICATION OF CHRONIC HEPATITIS C VIRUS...

Table (1): Demographic and clinical parameters of our patients

\begin{tabular}{|c|c|c|c|c|}
\hline $\begin{array}{ll}\text { Parameters } & \text { Groups } \\
\end{array}$ & Controls & Group A & Group B & Group C \\
\hline Age, $($ years, Mean \pm SD) & $43.5 \pm 14.5$ & $41.4 \pm 12.7$ & $39.4 \pm 11.9$ & $42.6 \pm 10.9$ \\
\hline \multicolumn{5}{|l|}{ Sex } \\
\hline - $\quad$ Male, $n(\%)$ & $12(40 \%)$ & $36(42.4 \%)$ & $32(41 \%)$ & $32(41.6 \%)$ \\
\hline - $\quad$ Female, n $(\%)$ & $18(60 \%)$ & $49(57.6 \%)$ & $46(59 \%)$ & $45(58.4 \%)$ \\
\hline \multicolumn{5}{|l|}{ Duration of DM (years) } \\
\hline - Range & $1.2-3$ & $1-3$ & $1-6$ & $7-17$ \\
\hline - $\quad$ Mean \pm SD & $2.2 \pm 0.5$ & $1.9 \pm 0.7$ & $4.7 \pm 1.3$ & $13.1 \pm 2.5^{*}$ \\
\hline \multicolumn{5}{|l|}{ Family history of DM } \\
\hline - $\quad$ Positive, $\mathbf{n}(\%)$ & $15(50 \%) * *$ & $0(0 \%)$ & $5(6.4 \%)$ & $49(63.6 \%)$ \\
\hline - $\quad$ Negative, $n(\%)$ & $15(50 \%)$ & $85(100 \%)$ & $73(93.6 \%)$ & $28(36.4 \%)$ \\
\hline \multicolumn{5}{|l|}{ Type of antidiabetic medications: } \\
\hline - Insulin, n (\%) & $0(0 \%)$ & $11(12.9 \%)$ & $7(9 \%)$ & $52(67.5 \%)$ \\
\hline - $\quad$ Oral hypoglycemic drugs, n (\%) & $22(73.3 \%)$ & $69(81.2 \%)$ & $66(84.6 \%)$ & $25(32.5 \%)$ \\
\hline - $\quad$ No therapy, $\mathbf{n}(\%)$ & $8(26.7 \%)$ & $5(5.9)$ & $5(6.4 \%)$ & $0(0 \%)$ \\
\hline \multicolumn{5}{|l|}{ Liver disease } \\
\hline - Chronic hepatitis, n (\%) & $30(100 \%)$ & $85(100 \%)$ & $0(0 \%)$ & $0(0 \%)$ \\
\hline - $\quad$ Liver cirrhosis Child-A, n (\%) & $0(0 \%)$ & $0(0 \%)$ & $78(100 \%)$ & $0(0 \%)$ \\
\hline - Liver cirrhosis Child-B, n (\%) & $0(0 \%)$ & $0(0 \%)$ & $0(0 \%)$ & $77(100 \%)$ \\
\hline \multicolumn{5}{|l|}{ DAAs regimen for $\mathrm{HCV}$} \\
\hline - Sofosbuvir + Dalatasvir, n $(\%)$ & - & $85(100 \%)$ & $78(100 \%)$ & $0(0 \%)$ \\
\hline - Sofosbuvir+Daclatasvir+Ribavirin, n (\%) & - & $0(0 \%)$ & $0(0 \%)$ & $77(100 \%)$ \\
\hline Weight, kg (Mean \pm SD) & $72.8 \pm 7.1^{*}$ & $73.6 \pm 5.7$ & $72.0 \pm 3.9$ & $77.9 \pm 8.6$ \\
\hline Height, Cm $($ Mean \pm SD $)$ & $169.2 \pm 4.2^{*}$ & $167.8 \pm 3.3$ & $167.4 \pm 3.2$ & $167.8 \pm 4.2$ \\
\hline BMI, Kg/m² $($ Mean \pm SD $)$ & $25.4 \pm 4.0^{*}$ & $26.1 \pm 5.2$ & $25.7 \pm 3.8$ & $27.7 \pm 4.8$ \\
\hline
\end{tabular}

$*=$ Significant. $\mathrm{SD}=$ Standard deviation. $\mathrm{BMI}=$ Body mass index

There were statistically significant variations between our patient groups and controls as regard to alanine aminotransferase (ALT), aspartate aminotransferase (AST), total bilirubin, serum albumin, international normalized ratio, Child-Turcotte- Pugh classification of liver cirrhosis, $\alpha$-fetoprotein, plasma insulin, fasting plasma glucose, glycosylated hemoglobin, homeostatic model assessment insulin resistance, and HCV-RNA by PCR (Table 2).

Table (2): Laboratory characteristics of our patients

\begin{tabular}{|c|c|c|c|c|c|c|}
\hline \multirow{2}{*}{$\begin{array}{l}\text { Groups } \\
\text { Parameters }\end{array}$} & Controls & Group A & Group B & Group C & \multirow{2}{*}{$\mathbf{F}$} & \multirow{2}{*}{$P$ value } \\
\hline & Mean \pm SD & Mean \pm SD & Mean \pm SD & Mean \pm SD & & \\
\hline ALT (U/L) & $34.8 \pm 3.9$ & $45.9 \pm 11.2$ & $43.3 \pm 9.3$ & $49.1 \pm 10.4$ & 2.982 & 0.001 \\
\hline AST (U/L) & $31.1 \pm 4.3$ & $48.7 \pm 8.5$ & $46.4 \pm 7.3$ & $58.6 \pm 8.0$ & 3.639 & 0.001 \\
\hline $\begin{array}{l}\text { Total bilirubin } \\
(\mathrm{mg} / \mathrm{dL})\end{array}$ & $0.85 \pm 0.15$ & $1.06 \pm 0.09$ & $1.13 \pm 0.06$ & $1.30 \pm 0.11$ & 3.883 & 0.001 \\
\hline Albumin (gm/dL) & $3.74 \pm 0.16$ & $3.98 \pm 0.09$ & $3.74 \pm 0.16$ & $3.17 \pm 0.23$ & 6.260 & 0.001 \\
\hline INR & $1.37 \pm 0.15$ & $1.16 \pm 0.08$ & $1.37 \pm 0.16$ & $2.04 \pm 0.17$ & 5.041 & 0.001 \\
\hline CTP Score & $1.0 \pm 0.1$ & $1.1 \pm 0.1$ & $1.5 \pm 0.24$ & $2.6 \pm 0.3$ & 1.982 & 0.002 \\
\hline$\alpha$ fetoprotein(ng/mL) & $3.69 \pm 0.52$ & $5.71 \pm 1.56$ & $5.61 \pm 1.59$ & $5.80 \pm 1.87$ & 2.786 & 0.001 \\
\hline $\begin{array}{l}\text { Plasma insulin } \\
(\mathrm{mIU} / \mathrm{mL})\end{array}$ & $5.60 \pm 1.45$ & $14.35 \pm 4.37$ & $7.77 \pm 5.59$ & $11.59 \pm 7.39$ & 3.132 & 0.001 \\
\hline $\begin{array}{l}\text { Fasting plasma } \\
\text { glucose }(\mathrm{mg} / \mathrm{mL})\end{array}$ & $\begin{array}{c}128.57 \pm \\
16.74\end{array}$ & $\begin{array}{c}184.58 \pm \\
17.79\end{array}$ & $\begin{array}{c}136.27 \pm \\
24.40\end{array}$ & $155.43 \pm 34.02$ & 1.696 & 0.003 \\
\hline HbA1c (\%) & $7.15 \pm 0.17$ & $7.96 \pm 0.59$ & $7.59 \pm 0.41$ & $8.07 \pm 0.75$ & 3.474 & 0.001 \\
\hline HOMA-IR & $1.75 \pm 0.27$ & $6.57 \pm 2.18$ & $2.85 \pm 3.04$ & $4.98 \pm 3.94$ & 2.867 & 0.001 \\
\hline $\begin{array}{l}\text { HCV-RNA by PCR } \\
\text { (IU/mL) }\end{array}$ & $\begin{array}{l}78666.67 \pm \\
19700.05\end{array}$ & $\begin{array}{c}551541.18 \pm \\
356220.59 \\
\end{array}$ & $\begin{array}{c}501128.21 \pm \\
363093.97 \\
\end{array}$ & $\begin{array}{c}800259.67 \pm \\
291131.97 \\
\end{array}$ & 3.374 & 0.001 \\
\hline
\end{tabular}

ALT $=$ Alanine aminotransferase. AST $=$ Aspartate aminotransferase. INR= International normalized 
ratio. $\mathrm{CTP}=$ Child-Turcotte-Pugh.

HbA1c=Glycosylated hemoglobin. HOMA-IR=

Homeostatic model assessment-Insulin resistance.

Three months following DAAs therapy, the main value of reduction in fasting plasma glucose and $\mathrm{HbAlc}$ in group 'A' was $32.9 \mathrm{mg} / \mathrm{dl}$ and $0.66 \%$, respectively, with a maximum reduction of $20 \mathrm{mg} / \mathrm{dl}$ and $0.7 \%$ respectively in almost of our patients. In group 'B' the main value of reduction in fasting plasma glucose and $\mathrm{HbA} 1 \mathrm{c}$ was $29.5 \mathrm{mg} / \mathrm{dl}$ and $0.53 \%$, respectively, with a maximum reduction of $80 \mathrm{mg} / \mathrm{dl}$ and $1.3 \%$ respectively, in most of our patients in this group. In group ' $\mathrm{C}$ ' the main value of reduction in fasting plasma glucose and
HbA1c was $9.47 \mathrm{mg} / \mathrm{dl}$ and $0.27 \%$, respectively, with a maximum reduction of $10 \mathrm{mg} / \mathrm{dl}$ and $0.3 \%$ respectively, in most of our patients in this group. There were statistically significant variations as regard to plasma insulin concentrations, homeostatic model assessment (HOMA) insulin resistance (HOMA-IR), alphafetoprotein, and HCV-RNA by PCR between the three groups of our patients with a statistically significant reduction in plasma insulin level, fasting plasma glucose, and glycosylated hemoglobin, alpha fetoprotein, and HCV-RNA by PCR in group A, B, and C (Table 3).

Table (3): Plasma insulin, fasting plasma glucose, HbA1c, HOMA-IR, $\alpha$-fetoprotein, and HCV-RNA by PCR before DAAs, and three months after therapy

\begin{tabular}{|c|c|c|c|c|c|c|c|c|}
\hline \multirow{3}{*}{ Groups } & \multirow{2}{*}{\multicolumn{2}{|c|}{$\begin{array}{c}\text { Group A } \\
\text { Mean } \pm \text { SD }\end{array}$}} & \multirow{2}{*}{\multicolumn{2}{|c|}{$\frac{\text { Group B }}{\text { Mean } \pm \text { SD }}$}} & \multirow{2}{*}{\multicolumn{2}{|c|}{$\begin{array}{c}\text { Group C } \\
\text { Mean } \pm \text { SD }\end{array}$}} & \multirow{3}{*}{$\mathbf{F}$} & \multirow{3}{*}{$\begin{array}{c}\mathbf{P} \\
\text { value }\end{array}$} \\
\hline & & & & & & & & \\
\hline & $\begin{array}{l}\text { Before } \\
\text { DAAs } \\
\end{array}$ & $\begin{array}{c}\text { After } \\
\text { DDAs } \\
\end{array}$ & $\begin{array}{l}\text { Before } \\
\text { DAAs }\end{array}$ & $\begin{array}{c}\text { After } \\
\text { DDAs }\end{array}$ & $\begin{array}{l}\text { Before } \\
\text { DAAs }\end{array}$ & $\begin{array}{l}\text { After } \\
\text { DDAs }\end{array}$ & & \\
\hline $\begin{array}{l}\text { Plasma } \\
\text { Insulin } \\
(\mathrm{mIU} / \mathrm{ML})\end{array}$ & $\begin{array}{c}14.35 \pm \\
4.38\end{array}$ & $\begin{array}{c}13.15 \pm \\
3.03\end{array}$ & $\begin{array}{c}7.77 \pm \\
5.59\end{array}$ & $\begin{array}{c}6.73 \pm \\
3.51\end{array}$ & $\begin{array}{c}11.60 \pm \\
7.39\end{array}$ & $\begin{array}{c}11.50 \pm \\
7.38\end{array}$ & 28.54 & 0.001 \\
\hline FPG (mg/dL) & $\begin{array}{c}184.57 \pm \\
17.79\end{array}$ & $\begin{array}{c}151.71 \pm \\
16.53\end{array}$ & $\begin{array}{c}136.27 \pm \\
24.40\end{array}$ & $\begin{array}{c}106.79 \pm \\
15.60\end{array}$ & $\begin{array}{c}155.43 \pm \\
34.02\end{array}$ & $\begin{array}{c}145.96 \pm \\
36.90\end{array}$ & 55.74 & 0.001 \\
\hline HbA1c (\%) & $\begin{array}{c}7.96 \pm \\
0.59\end{array}$ & $\begin{array}{c}7.30 \pm \\
0.48\end{array}$ & $\begin{array}{c}7.60 \pm \\
0.41\end{array}$ & $\begin{array}{c}7.07 \pm \\
0.37\end{array}$ & $8.07 \pm 0.75$ & $\begin{array}{c}7.80 \pm \\
0.73\end{array}$ & 24.33 & 0.001 \\
\hline HOMA -IR & $\begin{array}{c}6.57 \pm \\
2.18 \\
\end{array}$ & $\begin{array}{c}5.02 \pm \\
1.35 \\
\end{array}$ & $\begin{array}{c}2.85 \pm \\
3.04 \\
\end{array}$ & $\begin{array}{c}1.91 \pm \\
1.36 \\
\end{array}$ & $4.98 \pm 3.94$ & $\begin{array}{c}4.74 \pm \\
3.88 \\
\end{array}$ & 31.75 & 0.001 \\
\hline $\operatorname{AFP}(n g / d L)$ & $\begin{array}{c}5.71 \pm \\
1.56\end{array}$ & $\begin{array}{c}5.25 \pm \\
1.65\end{array}$ & $\begin{array}{c}5.61 \pm \\
1.59\end{array}$ & $\begin{array}{c}5.13 \pm \\
1.64\end{array}$ & $5.80 \pm 1.88$ & $\begin{array}{c}5.41 \pm \\
1.85\end{array}$ & 14.36 & 0.001 \\
\hline $\begin{array}{l}\text { HCV RNA by } \\
\text { PCR (IU/ml) }\end{array}$ & $\begin{array}{c}551541.18 \\
\pm \\
356220.59\end{array}$ & $\begin{array}{c}7058.82 \\
\pm \\
46389.23\end{array}$ & $\begin{array}{c}501128.21 \\
\pm \\
363093.97\end{array}$ & $\begin{array}{c}10897.44 \\
\pm \\
73257.88\end{array}$ & $\begin{array}{c}800259.67 \\
\pm \\
291131.97\end{array}$ & $\begin{array}{c}61818.18 \\
\pm \\
168536.48\end{array}$ & 7.10 & 0.001 \\
\hline
\end{tabular}

$\mathrm{FPG}=$ Fasting plasma glucose. HbA1c= Glycosylated Hemoglobin. HOMA-IR= Homeostatic model assessment-Insulin resistance.

There were statistically significant correlations between the sustained virologic response (SVR) with fasting plasma glucose, glycosylated hemoglobin, plasma insulin, and homeostatic model assessment-insulin resistance (HOMA-IR) in our patients pre and post therapy with DAAs (Table 4). 
Table (4): Correlation between FPG, Hb1c, plasma insulin and HOMA-IR before and after DAAs as regard to the sustained virologic response

\begin{tabular}{|c|c|c|c|c|c|}
\hline $\begin{array}{l}\text { Groups } \\
\text { Parameters }\end{array}$ & & Before DAAs & After DDAs & $\mathbf{r}$ & Significance \\
\hline FPG(mg/dL) & Mean \pm SD & $159.53 \pm 32.81$ & $135.27 \pm 31.70$ & 0.977 & 0.001 \\
\hline HbA1c $(\%)$ & Mean \pm SD & $7.88 \pm 0.63$ & $7.39 \pm 0.62$ & 0.800 & 0.001 \\
\hline Insulin (mIU/mL) & Mean \pm SD & $11.33 \pm 6.45$ & $10.54 \pm 5.66$ & 0.607 & 0.001 \\
\hline HOMA-IR & Mean \pm SD & $4.85 \pm 3.46$ & $3.92 \pm 2.82$ & 0.881 & 0.001 \\
\hline
\end{tabular}

$\mathrm{FPG}=$ Fasting plasma glucose. HbA1c= Glycosylated Hemoglobin. HOMA-IR= Homeostatic model assessment-Insulin resistance.

Multivariate regression analysis was done for adjustment of predicting factors, and the results revealed that diabetic control was achieved by the presence of the following factors: Child-Turcotte-
Pugh class A, negative family history for type $2 \mathrm{DM}$, shorter duration of type 2 $\mathrm{DM}$, and body mass index less than 30 (Table 5).

Table (5): Multivariate logistic regression analysis for factors affecting diabetic control with DAAs

\begin{tabular}{|l|c|c|c|c|}
\hline \multicolumn{1}{|c|}{ Analysis } & B & P value & Odds ratio & 95\% CI \\
\hline Variables & 0.721 & 0.012 & 0.881 & $0.198-0.972$ \\
\hline F.H of DM(Negative) & 0.917 & 0.001 & 2.95 & $1.995-4.250$ \\
\hline CTP score (Child A) & 0.862 & 0.021 & 0.422 & $0.203-0.878$ \\
\hline
\end{tabular}

$\mathrm{CI}=$ confidence interval. $\mathrm{DM}=$ diabetes mellitus. $\mathrm{F} \cdot \mathrm{H}=$ Family history. $\mathrm{CTP}=$ Child-Turcotte-Pugh.

\section{DISCUSSION}

The relationship between $\mathrm{HCV}$ infection and T2DM remains unclear, but has been widely hypothesized. The prevalence of diabetes mellitus in the United States population did not differ in patients with and/or without $\mathrm{HCV}$ infection in one study (Ruhl et al., 2014). On the other side, numerous studies support the link between these two conditions. Patients with chronic HCV infection are more susceptible to develop T2DM if compared to healthy individuals and patients with other chronic liver diseases (Hammerstad et al., 2015). The cause of T2DM in infected patients with $\mathrm{HCV}$ has been postulated to develop from either 'hepatogenous' T2DM arises from the advancement of liver disease or "classical" T2DM resulting from insulin resistance that is initiated by chronic $\mathrm{HCV}$ infection (Bose and Ray, 2014). The difference between 'hepatogenous' T2DM and "classical"T2DM is important; actually, as a result to different studies (Pashun et al., 2016 and Vanni et al., 2016), the 'classical' T2DM is considered clinically different from 'hepatogenous' T2DM, because the latter is less frequently associated with microangiopathy.

In this study, 226 (94.2\%) patients achieve the sustained virologic response (SVR), of whom 159 (70.4\%) had an improvement in blood sugar control following 3 months of direct acting antiviral therapy. In the achieved blood sugar control groups (group A, and B), 30 
patients $(36.1 \%)$, and 25 patients $(32.1 \%)$ respectively needed to decrease the dose of antidiabetic agents. Also, 5 patients in group A $(6.02 \%)$, and 5 patients in group B $(6.6 \%)$ not on any medications for type 2 diabetes mellitus had achieved diabetic control after 3 months of DAA therapy. No hypoglycemic events were not observed in our patients with baseline normal or near normal fasting plasma glucose and/or HbA1c, thus we excluded the hypoglycemic adverse effects of DAAs.

The effect of direct acting antiviral therapy on type 2 diabetes mellitus is disagreeing. One study concluded that deactivation of $\mathrm{HCV}$ with interferon- $\alpha$ or interferon- $\alpha$ plus Ribavirin treatment provided an important amelioration in blood sugar control in spite of the genotype (Miki et al., 2012). Another study founded that danoprevir therapy for $\mathrm{HCV}$ infection may reduce insulin resistance in genotype $1 \mathrm{HCV}$ patients (Moucari et al., 2010). In contrary with prior studies, a third study concluded that direct acting antiviral therapy with sofosbuvir and ledipasvir led to the development of new-onset T2DM (Premji et al., 2015).

Insulin resistance is supposed to initiate "classical" HCV-mediated T2DM, but the exact relationship remains uncertain. Previous studies revealed that HCV may deteriorate glucose homeostasis through two mechanisms, firstly via the direct effect of viral proteins, and secondly through modification of proinflammatory cytokine levels (Kawagushi and Sata, 2010). The HCV was shown to impede the hepatocyte insulin signaling pathway by several mechanisms: the viral core protein suppresses the insulin receptor substrate-1 (IRS-1) association with its insulin receptor by the increasing IRS-1 breakdown through upregulation of serine phosphorylation or increased activity of suppressor of cytokine signaling 3 (SOC3) (Del Campo et al., 2010 and Bose \& Ray, 2014). These effects on the insulin signaling pathway compromise downstream signaling and appropriate regulation of glucose homeostasis. Indirectly, $\mathrm{HCV}$-mediated production of the proinflammatory cytokines IL- 6 and TNF-alpha from sinusoidal liver cells impedes the insulin signaling pathways, thus enhancing gluconeogenesis (Antonelli et al., 2014). However, although HCV affects mainly the liver, the whole body peripheral insulin sensitivity is also compromised in $\mathrm{CHC}$ patients without metabolic syndrome, as shown by recent studies (Miquilena-Colina et al., 2011 and Petta et al., 2011).This suggests that the infected hepatocytes may be able to produce inflammatory mediators that encourage endocrine effects at extrahepatic sites, such as the skeletal muscle. The virus-prompted metabolic disturbances may react with hostconcerned genetic and environmental factors, exacerbating insulin resistance and perhaps leading to the development of T2DM (Bose and Ray, 2014).

In this study, there were statistically significant raised concentrations of plasma fasting glucose, HbAlc and HOMA-IR prior to DAAs therapy in our patients when compared with controls. Following sustained virologic response (SVR) with DAAs, the fasting plasma glucose and HbA1c levels were significantly decreased in patients who had achieved diabetic 
control (group A, and B), but not in group $\mathrm{C}$ (the non-achieved blood sugar control group with liver cirrhosis child B). Moreover, HOMA-IR were significantly improved 3 months after eradication of HCV with DAAs in all groups of our patients, but BMI was not a significant predictor in ameliorating diabetic control with DAAs therapy. Our results are in accordance with (Kawaguchi \& Mizuta, 2014) and (Vanni et al. 2016) who decided that eradication of $\mathrm{HCV}$ with DAAs improves both $\beta$-cell function and insulin resistance. Another study by ( $\mathrm{El}$ Zayadi and Anis , 2012) failed to prove this relationship. In this study, HOMA-IR was enhanced and correlated significantly with serum HCV-RNA concentrations 12 weeks following eradication of $\mathrm{HCV}$. Actually, non-significant changes in BMI pre- and post- DAA therapy, and the significant correlation of HOMA-IR with serum HCV-RNA levels, may indicate that viral replication has a direct role in the occurrence of IR. A latest study documents this hypothesis, showing an amelioration of IR in patients who established sustained virologic response after successful antiviral therapy. Furthermore, IR was more prevalent and IR predictors were elevated in chronic $\mathrm{HCV}$ patients than in chronic HBV patients chose as a control group in this study and very well correlated with chronic HCV patients as regard to clinical, biologic, and histologic features (Kawaguchi and Mizuta, 2014).

Effective eradication of $\mathrm{HCV}$ infection can ameliorate glucose homeostasis and reduce antidiabetic dosage requirements. In the current study, 30 patients $(36.1 \%)$ of group ' $\mathrm{A}$ ' needed to decrease the dose of antidiabetic treatment; 5 of 11 patients needed to reduce the insulin dose and 25 of 69 patients needed to reduce the Gliclazide dose, while 5 patients with no medications showed a significant reduction in both FPG and $\mathrm{HbA1c}$. In group 'B', 25 patients $(32.1 \%)$ needed to decrease the dose of antidiabetic medications; 4 out of 7 patients needed to reduce the insulin dose and 21 of 66 patients needed to reduce the Gliclazide dose but 5 patients with no medications showed a significant reduction in both FPG and HbA1c. In group C, 11 patients $(14.3 \%)$ needed to reduce the dose of antidiabetic medications; 6 out of 52 patients decreased the insulin dose, and 5 out of 25 patients decreased the dose of oral hypoglycemic drugs. None of the achieved blood sugar control patients (group A and B) needed to reduce the dose of dipeptidyl peptidase-4 (DPP4) inhibitors or metformin. A prior study explained an amelioration in non-insulin dependent T2DM when chronic HCV genotype 1 patients were successfully treated with pegylated-interferon alpha and ribavirin (Kim et al., 2009). Another study demonstrated an improvement of glycemic control confined to the treatment phase in an insulin-dependent T2DM patient with $\mathrm{HCV}$ who did not recover with interferon and ribavirin therapy (Huang et al., 2013). Another study determined an improvement of hyperglycemia in type $2 \mathrm{DM}$ patients treated with IFN- $\alpha$ and ribavirin for chronic HCV infection (Kawaguchi and Mizuta, 2014).

In our study, the percentage of patients with positive family history of T2DM significantly decreased in the achieved blood sugar control groups (group A, and B) compared with the non-achieved blood 
sugar control group (group C). In patients with negative family history of T2DM, the possibility of insulin resistance was most likely due to chronic HCV infection only. So, treatment of HCV infection, assisted in the amelioration of insulin resistance and hyperglycemia in contrast to those with hereditary insulin resistance. It might be useful to categorize patients into inherited IR or $\mathrm{HCV}$-mediated IR to understand the appropriate effect of eradication of $\mathrm{HCV}$ on type 2 diabetic patients with chronic HCV infection. Thus, in the absence of family history of T2DM in chronic HCV patients, the diagnosis of HCV-mediated IR was more likely. In this study, the longer the duration of type $2 \mathrm{DM}$, the more $\beta$-cell exhaustion and the less improvement in blood sugar control. This was evidenced from the shorter duration of type $2 \mathrm{DM}$ in achieved blood sugar control groups (group A $\{1-3$ years $\}$ and B $\{1-6$ years $\}$ ) if compared to group $\mathrm{C}$ (the non-achieved blood sugar control group) where the duration of type 2 diabetes mellitus ranged from 7-17 years. Our findings, as respected for the duration of type $2 \mathrm{DM}$ were in agreement with the results done by (Dawood et al., 2017) who concluded that, the duration of T2DM was significantly longer in the non-improved glycemic control group compared with the improved glycemic control group. Another study by (El-Zayadi and Anis, 2012) failed to document the role of DM duration in pathogenesis of insulin resistance.

In our study, a significant amelioration in diabetes control in the form of controlled FPG and HbA1c, was detected after effective eradication of $\mathrm{HCV}$ with DAA therapy. This improvement in diabetes control continued after eradication of viral infection during the duration of the study in spite of an increase in the patient's body mass index. Thus, controlling T2DM should be recommended before starting $\mathrm{HCV}$ therapy to raise the response rates (Ghany et al., 2009). However, with the future progresses in direct acting antiviral therapies, viral clearance not only possible, regardless of poor diabetic control, but also may be an effective measure of ameliorating diabetic control.

In this study, $29.6 \%$ of diabetic patients with non-achieved blood sugar control and had sustained virologic response (group C) did not achieve the diabetic control during the study period. This can be explained by several factors, i.e. patients with Child- Turcotte-Pugh class B were significantly higher in the non-achieved blood sugar control group, thus the severity of liver disease may play a significant role in the modification of diabetic control state. HCV infection may disturb glucose level by an immunemediated impairment of $\beta$-cells and is not related to IR. Thus, (Naing et al., 2012) suggested that $\mathrm{HCV}$ infection is more likely to initiate diabetes in genetically susceptible subjects. However, further genetic and environmental studies are required to explain the role of $\mathrm{HCV}$ in affecting glucose homeostasis. Almost all patients with Child-Turcotte- Pugh class B with non-achieved blood sugar control group had normal FPG and HbA1c. Our findings were in accordance with the results of (Dawood et al., 2017) as regard to uncontrolled diabetic control in ChildTurcotte- Pugh Class B patients (group C). The interconnection between liver fibrosis and IR is complex to assess. 
Because of the significance of the liver in carbohydrate metabolism and breakdown of insulin, progressive liver fibrosis may affect insulin clearance, resulting in an elevated plasma insulin levels despite of the status of insulin secretion. These findings revealed that the relationship between IR and HCV infection is initiated at early stages of liver disease. The main mechanism of the progression of fibrosis in relation to insulin resistance may be related to direct stimulation of hepatic stellate cells by hyperinsulinemia / hyperglycemia, leading to increased production of the connective tissue growth factor with resultant accumulation of extracellular matrix (Hsu et al., 2014).

In our study, the plasma insulin level was significantly elevated in our patients than controls, with a significant reduction in plasma insulin level following DAAs treatment, especially in patients with achieved blood sugar control groups (group A, and B). These suggested that hyperinsulinemia may be a presenting factor for the development of insulin resistance in type 2 diabetes mellitus that is associated with chronic HCV infection. The causes by which T2DM may induce chronic $\mathrm{HCV}$ infection are multifactorial. First, T2DM is a prevalent endocrine disorder in which insulin resistance (IR) is the main pathophysiologic event that is aggravated by excess glucose production from the liver, and / or a defect in insulin secretion, all of which participate in the occurrence of hyperglycemia in type 2 DM (Bugianesi et al., 2012 and Negro, 2014). Based on some in vitro studies, It has been suggested that replication of $\mathrm{HCV}$ may be facilitated by hyperinsulinemia and/or hyperglycemia observed in patients with IR and T2DM
(Kostandi et al., 2011 and Kukla et al., 2015). Moreover, T2DM may be associated with a reduced immune response, which leads to unbalanced immune dysfunction (Antonelli et al., 2014). Both IR and T2DM may play a role in the modification of the natural course of HCV infection, thus leading to enhanced liver changes in the form of steatosis, steatohepatitis, and liver fibrosis (Adinolfi et al., 2016 and Ballestri et al., 2016). Furthermore, most patients with diabetes mellitus often exposed to repeated blood extractions to perform blood sugar controls at home with the cooperation of family members. It would be instructive for diabetic patients to carry out a medical record established on the definitive risk factors accompanied with viral hepatitis (e.g. transfusion, hospitalization, and surgical operations) and other parameters that may affect the definitive alteration of hepatic function (e.g. alcohol abuse and hemochromatosis).

In this study, we have noticed that the serum alpha-fetoprotein at the baseline value significantly elevated in our patients with or without achieved diabetic control (group A, B, and C) if compared to controls. Three months following DAA therapy, the mean value of serum $\alpha$ fetoprotein significantly decreased in all groups of our patients. Based on these findings, AFP value may be used as an alternative biomarker for prediction of SVR. Performing AFP on starting therapy with DAAs (e.g. week 0 and week 4) rather than the polymerase chain reaction may be used as a biomarker to study the outcome of response to HCV therapy with DAAs and should be supported with future studies. Our results as regard to alpha-feto protein were in agreement with 
the findings observed by (Stine et al., 2017) who concluded that decreased AFP levels following treatment with DAAs may be used as a surrogate biomarker for likelihood of SVR.

\section{CONCLUSION}

In type 2 diabetes mellitus patients with uncontrolled hyperglycemia, the intake of direct acting antiviral agents led to a significant amelioration in blood sugar control and those patients should be closely observed for reduction of the dosage of anti-diabetic medications to prevent hypoglycemic episodes and also to adjust the dose of these medications either insulin or oral hypoglycemic agents before therapy with DAAs to augment the response rates. Clearance of $\mathrm{HCV}$ improves FPG, plasma insulin level, HbA1c and HOMA-IR. However, insulin resistance may be improved with clearance of $\mathrm{HCV}$ with DAA therapy. Improvement in diabetic control in patients with $\mathrm{HCV}$ treated with direct acting antiviral agents is of great value in patients with mild liver disease either chronic hepatitis or Child-Pugh class A liver cirrhosis, with short duration of diabetes, and with negative family history of T2DM, but is not correlated to body mass index, age, and sex. Prospective studies should be addressed to assess the long-term outcomes of direct acting antiviral agents on diabetic control, and to study the correlation between glycemic control and SVR with the future advances in DAAs. In addition, other studies should be conducted to discover the effect of regression in liver function tests after DAA therapy on the long term complications of T2DM.

\section{REFERENCES}

1. Adinolfi, L. E., Rinaldi, L., Guerrera, B., Restivo, L., Marrone, A., Giordano, M., and Zampino, R. (2016): NAFLD and NASH in $\mathrm{HCV}$ infection: prevalence and significance in hepatic and extrahepatic manifestations. International Journal of Molecular Sciences, 17(6): 803 .

2. Amer FA, Gohar M and Yousef M (2015): Epidemiology of hepatitis $C$ virus infection in Egypt. Int J Trop Dis Health, 7:119-31.

3. Antonelli A, Ferrari SM, Giuggioli D, Di Domenicantonio A, Ruffilli I, Corrado A, Fabiani S, Marchi S, Ferri C, Ferrannini E and Fallahi $P$ (2014): Hepatitis $C$ virus infection and type 1 and type 2 diabetes mellitus. World Journal of Diabetes, 5(5):586 600.

4. Bachofner, J. A., Valli, P. V., Kr?ger, A., Bergamin, I., Künzler, P., Baserga, A. and Semela, D. (2017): Direct antiviral agent treatment of chronic hepatitis $\mathrm{C}$ results in rapid regression of transient elastography and fibrosis markers fibrosis-4 score and aspartate aminotransferase-platelet ratio index. Liver International, 37(3): 369-376.

5. Ballestri, S., Nascimbeni, F., Romagnoli, D., Baldelli, E., Targher, G. and Lonardo, A. (2016): Type 2 Diabetes in non-alcoholic fatty liver disease and hepatitis $\mathrm{C}$ virus infectionLiver: The "Musketeer" in the spotlight. International Journal of Molecular Sciences, 17(3): 355-355.

6. Bose SK and Ray R (2014): Hepatitis C virus infection and insulin resistance. World Journal of Diabetes, 5: 52-58.

7. Bugianesi, E., Salamone, F. and Negro, F. (2012): The interaction of metabolic factors with HCV infection: does it matter? Journal of Hepatology, 56: S56-S65.

8. Chang ML (2016): Metabolic alterations and hepatitis C: From bench to bedside. WJG., 22: 1461-76.

9. Cho, N. H. (2016): Q\&A: Five questions on the 2015 IDF Diabetes Atlas. Diabetes Research and Clinical Practice, 115: 157-159.

10. Dai CY, Yeh ML, Huang CF, Hou CH, Hsieh MY, Huang JF and Lin IL (2015): 
Chronic hepatitis $\mathrm{C}$ infection is associated with insulin resistance and lipid profiles. J Gastroenterol Hepatol., 30: 879-884.

11. Dawood A A, Nooh Z M, and Elgamal A A (2017): Factors associated with improved glycemic control by direct acting antiviral agent treatment in Egyptian type 2 diabetes mellitus patients with chronic Hepatitis $\mathrm{C}$ genotype 4. Diabetes Metab J., 41: 316-321.

12. Del Campo, J. A., L?pez, R. A. and RomeroG?mez, M. (2010): Insulin resistance and response to antiviral therapy in chronic hepatitis C: mechanisms and management. Digestive Diseases, 28(1): 285-293.

13. El-Zayadi, A. R. and Anis, M. (2012): Hepatitis $\mathrm{C}$ virus induced insulin resistance impairs response to anti-viral therapy. World Journal of Gastroenterology, 18(3): 212-224.

14. Eslam M, Khattab $M$ and Harrison SA (2011): Insulin resistance and hepatitis $C$ : an evolving story. Gut, 60:1139-51.

15. Ghany MG, Strader DB, Thomas DL, and Seeff LB (2009): Diagnosis, management, and treatment of hepatitis C: an update. Hepatology, 49(4):1335-74.

16. Group IDFDA (2015): Update of mortality attributable to diabetes for the IDF Diabetes Atlas: estimates for the year 2013. Diabetes Res Clin Pract., 109(3): 461-5.

17. Hammerstad S S, Grock S F, Lee H J, Hasham A, Sundaram $\mathbf{N}$ and Tomer $\mathbf{Y}$ (2015): Diabetes and hepatitis C: a two-way association. Frontiers in Endocrinology, 6: 134134.

18. Hashim, A. E., Kandeel, H. T., Hendy, O. M., El-Mola, K., El-Raey, F. M. and Attia, M. S. (2017): Effect of new direct-acting antiviral drugs on insulin resistance and glycemic control after treatment of chronic hepatitis $\mathrm{C}$ virus infection in type 2 diabetic patients. Al-Azhar Assiut Medical Journal, 15(4): 187-187.

19. Hsu, Y. C., Lin, J. T., Ho, H. J., Kao, Y. H., Huang, Y. T., Hsiao, N. W. and Wu, C. Y. (2014): Antiviral treatment for hepatitis $C$ virus infection is associated with improved renal and cardiovascular outcomes in diabetic patients. Hepatology, 59(4): 1293-1302.
20. Huang, J. F., Yu, M. L., Dai, C. Y. and Chuang, W. L. (2013): Glucose abnormalities in hepatitis $\mathrm{C}$ virus infection. The Kaohsiung Journal of Medical Sciences, 29(2): 61-68.

21. Kaddai V and Negro F (2011): Current understanding of insulin resistance in hepatitis C. Expert Review of Gastroenterology \& Hepatology, 5:503-16.

22. Kawaguchi, Y. and Mizuta, T. (2014): Interaction between hepatitis $\mathrm{C}$ virus and metabolic factors. World Journal of Gastroenterology, 20(11): 2888-2901.

23. Kawaguchi, T. and Sata, M. (2010): Importance of hepatitis $\mathrm{C}$ virus-associated insulin resistance: therapeutic strategies for insulin sensitization. World Journal of Gastroenterology, 16(16): 1943-1952.

24. Kawaguchi T, Taniguchi E, Itou M, Sakata M, Sumie S and Sata M (2011): Insulin resistance and chronic liver disease. World $\mathbf{J}$ Hepatol. 3: 99-107.

25. Kim H J, Park J H, Park D I, Cho Y K, Sohn C I, Jeon W K, and Kim BI (2009): Clearance of HCV by Combination Therapy of Pegylated Interferon $\alpha-2 \mathrm{a}$ and Ribavirin Improves Insulin Resistance. Gut and Liver, 3 (2): 108-115.

26. Kostandi, I., Bahgat, M., Zayed, N. and Rashed, L. (2011): Assessment of insulin resistance and insulin growth factor-1 in Egyptian patients with chronic hepatitis C. Open Journal of Endocrine and Metabolic Diseases, 1(1), 1: 1-8.

27. Kukla, M., Piotrowski, D., Waluga, M. and Hartleb, M. (2015): Insulin resistance and its consequences in chronic hepatitis C. Clinical and experimental hepatology, 1(1), 17-29.

28. Meissner, E. G., Lee, Y. J., Osinusi, A., Sims, Z., Qin, J., Sturdevant, D. and Patel, K. (2015): Effect of sofosbuvir and ribavirin treatment on peripheral and hepatic lipid metabolism in chronic hepatitis $\mathrm{C}$ virus, genotype 1-infected patients. Hepatology, 61:790-801.

29. Miki, D., Ohishi, W., Ochi, H., Hayes, C. N., Abe, H., Tsuge, M. and Chayama, K. (2012): Serum PAI-1 is a novel predictor for response to pegylated interferon- $\alpha-2 b$ plus ribavirin 
therapy in chronic hepatitis $\mathrm{C}$ virus infection. Journal of Viral Hepatitis, 19(2): e126-e133.

30. Milner, K.L., van der Poorten, D., Trenell, M., Jenkins, A.B., Xu, A., Smythe, G., Dore, G.J., Zekry, A., Weltman, M., Fragomeli, V. and George, J. (2010): Chronic hepatitis $C$ is associated with peripheral rather than hepatic insulin resistance. Gastroenterology, 138:93241.

31. Miquilena-Colina, M. E., Lima-Cabello, E., S?nchez-Campos, S., Garç-Mediavilla, M. V., Fern?ndez-Bermejo, M., LozanoRodr?guez, T. and Gonz?lez-Gallego, J. (2011): Hepatic fatty acid translocase CD36 upregulation is associated with insulin resistance, hyperinsulinaemia and increased steatosis in non-alcoholic steatohepatitis and chronic hepatitis C. Gut, 60 (10): 1394-1402.

32. Moucari R, Forestier N, Larrey D, Guyader D, Couzigou P, Benhamou Y, Voitot $\mathbf{H}$, Vidaud M, Seiwert S, Bradford $B$ and Zeuzem S (2010): Danoprevir, an HCV NS3/4A protease inhibitor, improves insulin sensitivity in patients with genotype 1 chronic hepatitis C. Gut, 59(12):1694-8.

33. Naing C, Mak JW, Ahmed SI, and Maung M (2012): Relationship between hepatitis $C$ virus infection and type 2 diabetes mellitus: meta-analysis. World J Gastroenterol., 18:164251.

34. Negro F (2014): Facts and fictions of HCV and comorbidities: steatosis, diabetes mellitus, and cardiovascular diseases. Journal of Hepatology, 61: S69-78.

35. Pandya, P., Pant, C., Taylor, R. and Oni, O. (2017): Impact of sustained virological response to chronic hepatitic $\mathrm{C}$ antiviral therapy on new onset diabetes mellitus type 2 after controlling for metabolic syndrome. Journal of Investigative Medicine, 65(4): 765-771.

36. Pashun, R. A., Shen, N. T. and Jesudian, A. (2016): Markedly improved glycemic control in poorly controlled type 2 diabetes following direct acting antiviral treatment of genotype 1 hepatitis C. Case Reports in Hepatology, 1:1.

37. Pazienza V, Vinciguerra M, Andriulli A and Mangia, A. (2010): Hepatitis C virus core protein genotype $3 \mathrm{a}$ increases SOCS-7 expression through PPAR- $\gamma$ in Huh-7 cells. Journal of General Virology, 91:1678-86.

38. Persico, M., Roberta, R., Persico, E., Svelto, M. F., Spano, D., Andolfo, I. and Torella, R. (2009): SOCS3 and IRS-1 gene expression differs between genotype 1 and genotype 2 hepatitis $\mathrm{C}$ virus-infected HepG2 cells. Clinical Chemistry and Laboratory Medicine, 47:121725.

39. Petta, S., Cammà, C., Di Marco, V., Macaluso, F. S., Maida, M., Pizzolanti, G. and Guarnotta, C. (2011): Hepatic steatosis and insulin resistance are associated with severe fibrosis in patients with chronic hepatitis caused by $\mathrm{HBV}$ or $\mathrm{HCV}$ infection. Liver International, 31(4): 507-515.

40. Premji R, Roopnarinesingh N, Qazi N, and Nylen ES (2015): New-onset diabetes mellitus with exposure to ledipasvir and sofosbuvir. J Investig Med High Impact Case Rep., 3:2324709615623300.

41. Ruhl CE, Menke A, Cowie C.C and Everhart JE (2014): Relationship of hepatitis $C$ virus infection with diabetes in the U.S. population. Hepatology, 60 (4): 1139-1149.

42. Stine G J, Wynter A J, Niccum B, Kelly V, Caldwell H S and Shah L N (2017): Effect of Treatment with Direct Acting Antiviral on Glycemic Control in Patients with Diabetes Mellitus and Chronic Hepatitis C. Annals of Hepatology, 16 (2):215-220.

43. Vanni E, Abate $M L$ and Gentilcore $E$ (2009): Sites and mechanisms of insulin resistance in non-obese, nondiabetic patients with chronic hepatitis C. Hepatology, 50:697706.

44. Vanni E, Bugianesi E and Saracco G (2016): Treatment of type 2 diabetes mellitus by viral eradication in chronic hepatitis C: Myth or reality? Digestive and Liver Disease, 48: 105111.

45. White DL, Ratziu $V$ and El-Serag HB (2008): Hepatitis $\mathrm{C}$ infection and risk of diabetes: a systematic review and metaanalysis. Journal of Hepatology, 49:831-44. 
نتائج عو امل مضادات الفيروسات المباشرة لعلاج الإلتهاب

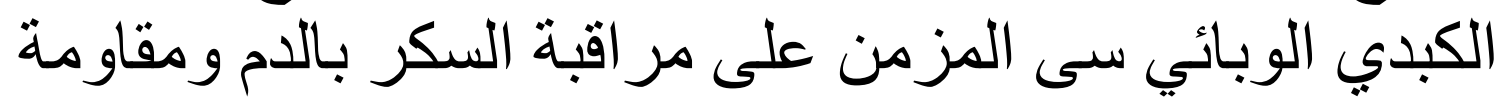

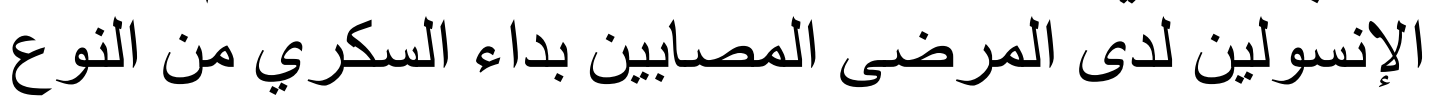
الثاني

عرفات عبد العظيم قاسم* ـ مبروك محمود ابو العينين*** ـ محمد عبد الحميد خضر ***

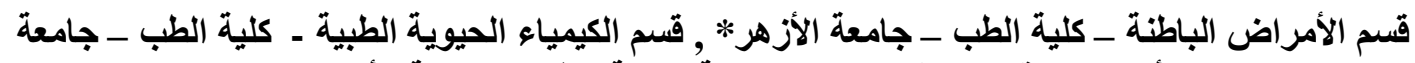

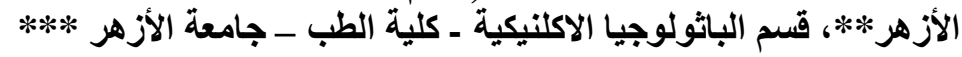

خلقية البحث : يمكن أن تؤدى عدوى الاصـابة بفيروس الإلتهاب الكبدي الوبائي (سـي) إلى زيـادة في احتمال الإصـابة بمرض السكري من النوع الثانى في الأشخاص المعرضين للمرض بشكل مستقل عن مرحلـة مـرض الكبد. وتشـل الطرق التي من خلالهـا الثـروع فى إبتداء السكرى من النوع الثانى بواسـة الإلتهاب الكبدى الفيروسى سـى وهـى الفعاليـة المباثـرة لـفيروس سـى ومقاومـة إلإنسـولين و السيتوكينات المسببة للإلتهاب و آليات أخرى بوساطة الجهاز المناعي.

الـهـف من البحث: تقييم نتائج الأدويـة المضـادة للفيروسـات المباشـرة لعـلاج العدوى بفيروس إلتهاب الكبد الوبـائي سـى المزمن على مقاومـة الإنسولين ومر اقبـة السكر في الدم لـى المرضـى المصـابين بالنوع الثاني من داء السكري.

المرضى وطرق البحث: أجريت هذه الدر اسة على مائتين وسبعين مريضا من النوع الثاني من مرضى السكري مـع النمط الور اثي الر ابع من الإلتهاب الكبدى الفيروسى سـى المزمن. وقد تعرض مائتان واربعين مريضًا لـمضادات الفيروس المباثـرة على شكل عقار سوفوسبوفير ، بالإضـافة إلى عقار دكلاتاسفير مع أو بدون عقار ريبافيرين لمدة اثنى عشر أسبوعًا ، في حين أن ثلاثين مريضًا متبقيًا لم يتم إعطـائهم مضـادات الفيروس المباشـرة، واستخدمو اكمجموعـة مقارنـة. وقد تم تصنيف المرضـى الذين بلغوا الإثتى عشـر أسبو عًا مـن الإستجابة المستدامة للفيروس(مائتان وستة و عشرون مريضًا 6بمعدل r, ؟ 9\%) إلى ثـلاث مجموعـات إستنادًا إلى نقطة النهايـة للتحكم في سكر الدم، ومجمو عـة السبطرة على نسبة السكربالدم التي تم التوصل إليها مـع إلتهاب الكبد المزمن (المجموعـة أ) و التي

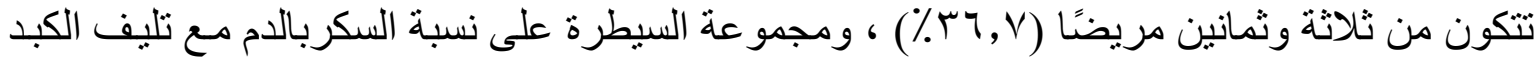
اتشيلد " ا " (المجمو عـة ب) و التي شملت ستة وسبعين مريضًا (ج, سب\%)، ومجموعة عدم السبطرة على نسبة السكر في الدم مع تليف الكبد اتشيلد "ب" (المجموعة س) التي شملت سبعة وستين مريضـا 


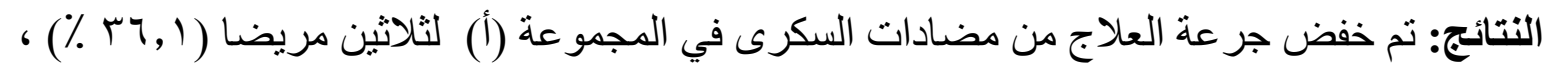

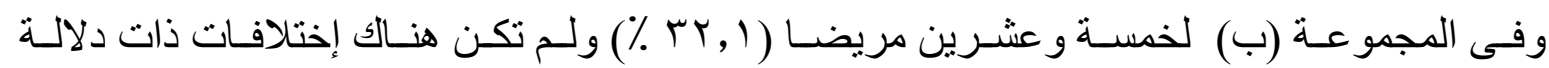

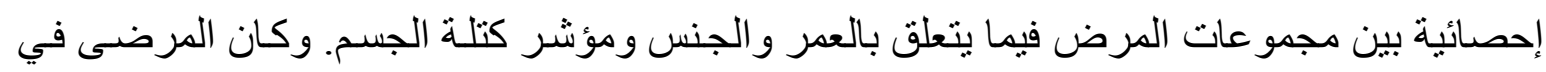

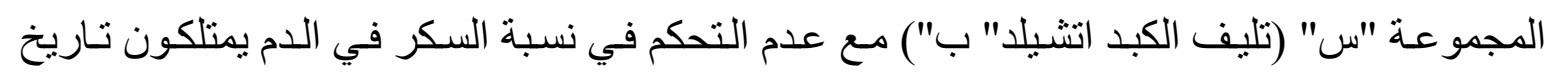

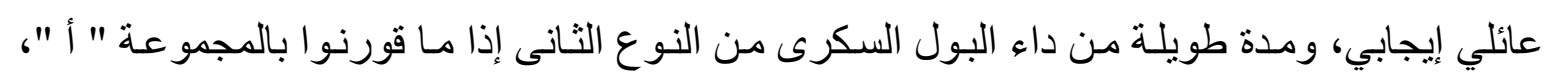

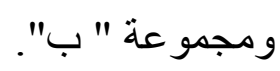

الاستنتاج: في المرضى المصابين بالبول السكري من النوع الثاني و المصابين بإلتهاب الكبد الوبائي

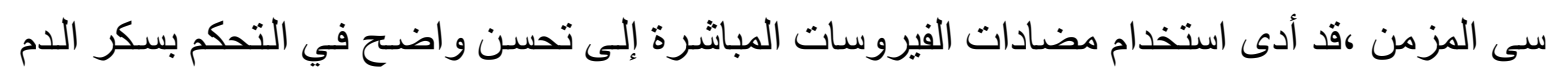

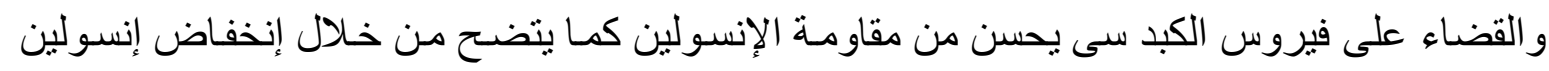

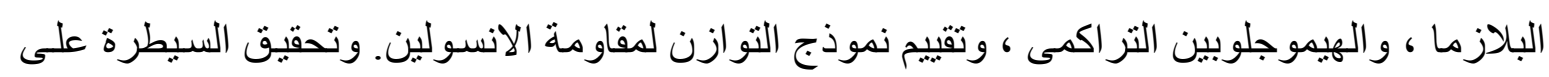

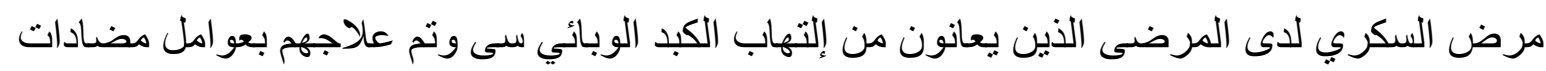

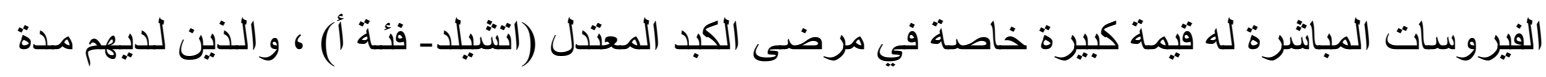

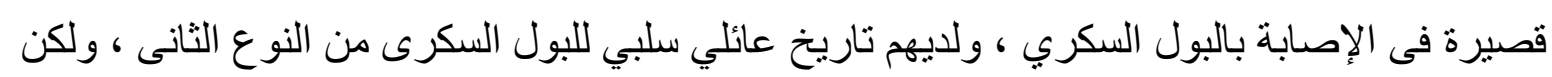
ليس مرتبطا بمؤشر كتلة الجسم و العمر و الجنس. 